\title{
全国地盤物性データベースを用いた地中熱利用 ヒートポンプ暖房システムの導入効果分析
}

\author{
阪田 義隆 ${ }^{*}$ ・葛 隆生 ${ }^{2} \cdot$ 長野 克則 ${ }^{3}$ \\ ${ }^{1}$ 正会員 北海道大学大学院特任准教授 工学研究院（ $\bar{T} 060-8628$ 北海道札幌市北区北13西8） \\ E-mail: y-sakata@eng.hokudai.ac.jp \\ 2非会員 北海道大学大学院准教授 工学研究院（干060-4628北海道札幌市北区北13西8） \\ E-mail: katsura@eng.hokudai.ac.jp \\ 3非会員 北海道大学大学院教授 工学研究院（广060-5628北海道札幌市北区北13西8） \\ E-mail: nagano@eng.hokudai.ac.jp
}

\begin{abstract}
本研究の目的は, 開発した全国地盤物性データベースからの有効熱伝導率の三次元情報と地中熱シミュ レーションを組み合わせ，地中熱利用ヒートポンプ暖房システムを戸建て住宅に導入した場合の環境負荷 低減効果を計算し，北日本全体の地中熱ポテンシャルマップとして示すことである。 その際，期間平均成 績係数 $(\overline{\mathrm{COP}})$ を導入指標とし, 目標 $\overline{\mathrm{COP}}$ を得るための地中熱交換器長さ $L_{\mathrm{b}}$ の決定法を提案する. その結果, 標淮的な $L_{b}=100 \mathrm{~m}$ のシステムを戸建て住宅に導入する場合, $\overline{\mathrm{COP}}$ は北海道で 4.0 程度, 東北以南で 4.4 程度 と計算された。より合理的な導入のため, 目標 $\overline{C O P} を 4.25$ に設定する場合, 東北以南で $L_{b}=80 \mathrm{~m}$ 程度とよ り短く, 北海道で $130 \mathrm{~m}$ 程度とより長く必要になると計算された. $\mathrm{CO}_{2}$ 排出量削減率は, $45 \sim 60 \%$ 程度と 電力使用時の排出係数に依存し, 東北以南で高い導入効果が示された.
\end{abstract}

Key Words : ground source heat pump system, geologic property database, potential map, design optimization, $\mathrm{CO}_{2}$ emission

\section{1. はじめに}

再生可能エネルギーの内，地中熱は深度200 $\mathrm{m}$ 付近よ り以浅の安定した熱エネルギーであり，建物の空調設備 の熱源とする地中熱利用ヒートポンプシステム(Ground Source Heat Pump system: GSHPs)による利用が進んでいる1) わが国でも2000年代以降，導入数が急速に増えつつある が22,3)，北欧・北米などに比べ未だ大きな開きがある.

GSHPsの導入効果の一つに，安定な熱源を用いた高い エネルギー効率がもたらす省エネルギーと $\mathrm{CO}_{2}$ 排出量抑 制などの環境負荷低減効果が挙げられる．その導入効果 は個別導入事例にて数多く報告され，空気熱源ヒートポ ンプ(エアコン: ASHP)と比べても高い省エネルギー効果 が期待できることが分かっている47など. 今後, GSHPsの 優位性の認知が進み，現在の個別導入が広域的に普及拡 大寸ることで，GSHPsの環境負荷低減効果が地域・国レ ベルで発揮され，地球温暖化対策に繋がると期待される

一方, GSHPsの導入効果は, 建物の断熱性や用途, 気 象条件, ヒートポンプ，地中熱交換器その他付帯設備な どが複合して決まる．例えば，建物のエネルギ一消費性
能判定WEBプログラム8)でもGSHPs導入時の評価が可能 だが, GSHPsの知識や導入経験がない場合, 様々な計算 条件の設定を忌避する結果, 他システムとの比較が十分 なされることなく，導入が見送られることが賏念される． このような背景において，GSHP導入を検討する施工 主や設計者あるいは補助事業を推進する国や自治体が, その導入効果を容易に判断できる「地中熱ポテンシャル マップ」の整備が必要となる9!。地中熱ポテンシャルマ ップとは，数值計算や地理情報システム(GIS)などの技 術を用いて, システム効率, コスト, 省エネ効果など GSHPs導入効果指標を広範囲で示したものである. 地中 熱ポテンシャルマッピングは，これまでに多くの研究成 果10-15)があるほか，国10や自治体 ${ }^{17-20}$ も盛んに実施してき た. 近年は各地で地中熱マッピングが取り組まれる現状 から，用語の定義や手法の規格化を進める動きがある21). 地中熱ポテンシャルマッピングにおいて課題となるの が地盤物性，特に有効熱伝導率の分布推定である. 有効 熱伝導率の土質・地質毎の一般值をまとめた文献やデー タベースは多い222\%ど。しかし実際の地盤は不均質であり， 例えば同じ砂層でも, 淘汰のよい砂の場合と㗜や泥が混 
じる場合，その頻度で有効熱伝導率は異なる23)。また地 下水流れが速い場合，見掛けの值が増加寸る場合もある 24). 有効熱伝導率のデータベースは，土質・地質の一般 值ではなく, 地域の地層構造から各層の土質・地質の複 雑さや地下水流れの影響まで含め, 地点毎に推定寸る必 要があるが，その推定手法は確立されていなかった。

更にボアホール間接型の地中熱交換器を想定する場合, 少なくとも標準的な埋設深度 $100 \mathrm{~m}$ までのデータベース とする必要があるが，既往の地盤調査の大半は深度数 10 m以浅の支持層確認で調查を終える．例えば「KuniJiban」 25)で検索すると, 全110946地点のコアボーリングデータ 中, 深度 $100 \mathrm{~m}$ に達寸るデータは 584 データ（全体の $0.5 \%$ ) に留まる，このため，物性值（現位置試験結果）の入手 どころか地質データそのものの入手も困難となる.

これらの課題を踏まえ, NEDO「自然再生可能エネル ギ一熱利用技術開発」20の一つとして，全国地盤物性デ 一タベースの開発が進められている27, 28)六ど。全国地盤物 性データベースは，地中熱計算のみならず比較的深い深 度での地下開発全般への利用を想定し, 深度 $100 \mathrm{~m}$ 付近 までを対象に，有効熱伝導率や透水係数などの地盤物性 を地質区分の分布確率から推定し，全国を網羅する三次 元グリッドにて提供するデータベースである. この全国 地盤データベースを用いることで, 複数の都道府県にま たがる地中熱ポテンシャルマップを同一のデータ・手法 で作成することができ，GSHP導入効果を広域で比較分 析することが可能となる。 こうした広域ポテンシャルマ ップは, 各地域で詳細なポテンシャルマップを作成する 場合のリファレンスマップの役割も担えると期待される。

本研究では, 暖房負荷が大き $<\mathrm{CO}_{2}$ 排出量削減効果が 見込める北日本（北緯 $36^{\circ}$ 以北）を対象に，全国地盤デ ータベースの有効熱伝導率データと地中熱シミュレーシ ヨンを組み合わせた地中熱ポテンシャルマップを示す. ここでは, 戸建て住宅へのGSHP導入を想定し，(1)地中 熱交換器の標準長さ $(100 \mathrm{~m})$ に対する期間平均の成績係数 (Coefficient Of Performance: COP), (2)GSHPsの導入規模の目 安となる目標期間平均COPに対寸る地中熱交換器長さ, (3)GSHPs導入による $\mathrm{CO}_{2}$ 排出量削減率を計算, マッピン グし, これらの地域比較から導入効果の分析を行う.

\section{2. 研究手法}

\section{（1） 全国地盤物性データベース}

全国地盤物性データベースの特徽は, a. 深度 $100 \mathrm{~m}$ 付 近までを対象とす心゙く，コアボーリングデータの不足を 補うため, 地下水利用井戸の掘削記録（井戸データ）を 併せて用いる， b. 三次元グリッドにて存在しうる全ての 地質区分の分布確率をクリギング推定しデータベースと する，c. 固有物性值と分布確率の重㸚合わせにより有効
熱伝導率などの地盤物性值を推定する点にある.これら 特徵は既に報告されており 27, 28)，ここでは手法の概要と 本研究で追加した点について述べる.

図-1に，対象地域において収集・利用した地質データ を示す.コアボーリングデータは先述の Kunijiban より 深度 $30 \mathrm{~m}$ 以上に絞り 1514 点，コアボーリングデータの 不足を補うために用いる井戸データは「いどじびき」29) より 2172 点, 「地下水 (深井戸) 資料台帳」30)から 15395 点を用いた. データの平均深度は $109 \mathrm{~m}$ であった. 地質デー夕は深度ごとの地質分布を多様な名称で記載 しているが，これを大きく 8 種類（未固結な「土」を 4 種類：「粘性土」，「砂質土」，「碩質土」，「火山灰 質土」，固結した「岩」を 4 種類 : 火山地域に多く現れ る「第四紀火山岩」，固結度の低い新第三紀の「泥質 岩」，「砂岩・線岩」，固結度の高い「基盤岩（その 他）」）に分類し，深度 $1 \mathrm{~m}$ 毎に整理した. その際の地 質形成年代の判定には「三次元水文地質モデル」 ${ }^{311} の$ 地 層区分を用いた．なお同モデルでは，第四紀と新第三紀 の地質年代境界を約 180 万年前としており, 近年定めら れた年代定義（約 260 万年前） ${ }^{32)}$ と異なることに留意す る必要がある。

この地質データを用い，三次元グリッドでの任意地 点・深度にて, 全ての地質区分 $(k=1 \sim 8)$ の分布確率を, インディケータクリギングにより推定する ${ }^{33)}$.

$$
p_{\text {IK }}(\boldsymbol{u} ; k)=\sum_{\alpha=1}^{n} \mu_{\alpha}(k)\left[i\left(\boldsymbol{u}_{\alpha} ; k\right)-p(k)\right]+p(k)
$$

ここで， $p_{\mathbb{K}}(\boldsymbol{u} ; k)$ は地質区分 $k$ が任意地点 $\boldsymbol{u}$ に出現する確 率， $i\left(\boldsymbol{u}_{c} ; k\right)$ はインディケータと呼ばれ，地質区分 $k$ がデ 一夕 $\alpha$ の位置 $\boldsymbol{u}_{\alpha}$ に出現する場合に 1 , 他の地質区分の場 合は 0 を与える. $p(k)$ は地質区分 $k$ の平均分布確率， $\mu_{\alpha}$ はクリギング係数で，インディケータデータから推定し

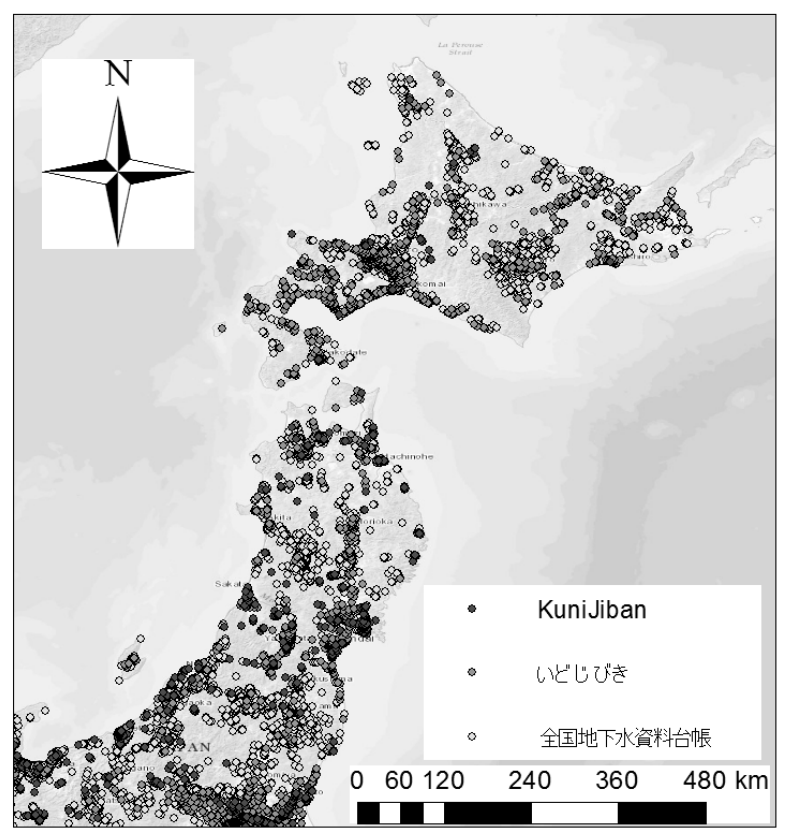

図-1 研究に用いた地質データ 
たバリオグラムによる連立線形方程式を解いて求まる.

推定に用いるデータは，推定点を中心とする探索半径 内で, かつ推定点と同一の地形分類および地層分類に属 するものを用いた. この際，地形分類や地層分類の判定 は「国土数值情報（土地分類メッシュ）」 ${ }^{34}$ および三次 元水文地質モデルに基づき行う.なお地形分類は元々の 35 種類の分類（主分類）を 5 種類（「山地」, 「丘陵 地」，「山麓・扇状地」，「台地」，「低地」）に再分 類した. 井戸データの探索半径とバリオグラムの異方性 は, 推定結果が井戸データの地質と最も一致する組み合 わせをあらかじめ交差検証法により把握し，推定点毎の 条件に応じた最適な組み合わせを逐次決定している ${ }^{27}$.

地質推定のグリッド間隔は任意だが，ここでは北日本 全体のマップとして視覚的に分かりやすい $10 \mathrm{~km}$ グリッ ドを採用した．深度方向の推定は，井戸データの記録精 度を勘案し $5 \mathrm{~m}$ とし, 深度 $225 \mathrm{~m}$ まで推定を行った. 本 システムでは深度 $100 \mathrm{~m}$ 付近までを主な対象とするが, より深い深度にもそのまま適用可能である. ただし, 井 戸データがない深度では上位の地質区分が連続すると仮 定し，新第三紀以前の層に該当する深度では全て基盤 $(k=8)$ と仮定した. 探索半径の最大距離は $5 \mathrm{~km}$ とし, デ ータが乏しい山間部ではクリギング推定に代えて，10 $\mathrm{km}$ グリッド中の井戸データによる平均分布 $p(k)$ を推定 結果とした. 更に $10 \mathrm{~km}$ 格子内にデータが無い場合, 国 土数值情報に含まれる「表層地質分類」を 8 地質区分に 分類し, 分布確率 1 を与えた. その際, 分類が「岩 $(k=5$ ～8)」の場合，表層の第四紀層は地形毎に山地，丘陵地， 台地は砂質土 $(k=2)$, 山麓・扇状地にて碩質土 $(k=3)$, 低 地にて粘性土 $(k=1)$ に分類し, 「土」の場合, 第三紀以

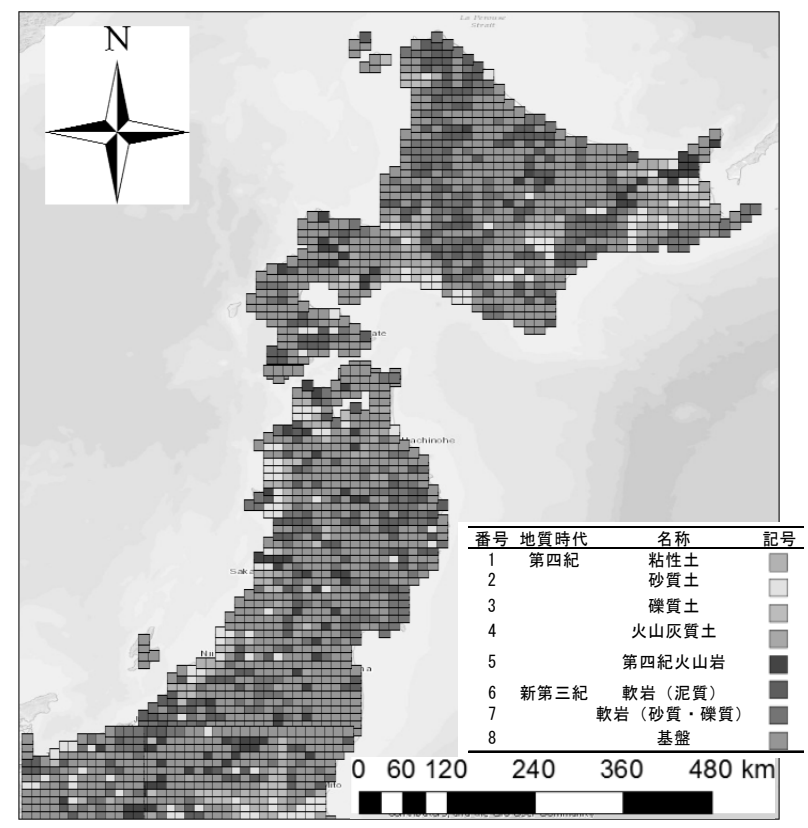

図-2 深度 $50 \mathrm{~m}$ の最大分布確率の地質区分（10 km グリッド）
前の層は全て基盤 $(k=8)$ とした.

図-2に，検討範囲における深度 $50 \mathrm{~m}, 10 \mathrm{~km}$ グリッド （計 2129 点）での最大分布確率の地質区分を示す. 従 来の地質図は表層付近の地質を示すに留まったが，本デ ータベースでは任意深度の地質をグリッドで図示寸るこ とができる．更に分布確率の情報も有するため，地質分 布の複雑さや推定の不確実性の評価も可能である ${ }^{27}$. わ が国では山地が大半を占め, 全体に基盤 $(k=8)$ が分布し つつ, 臨海部や大河川沿いは未固結層 $(k=1 \sim 4)$ が，火山 周辺は火山灰 $(k=4)$ や火山岩 $(k=5)$ が，局所的に新第三紀

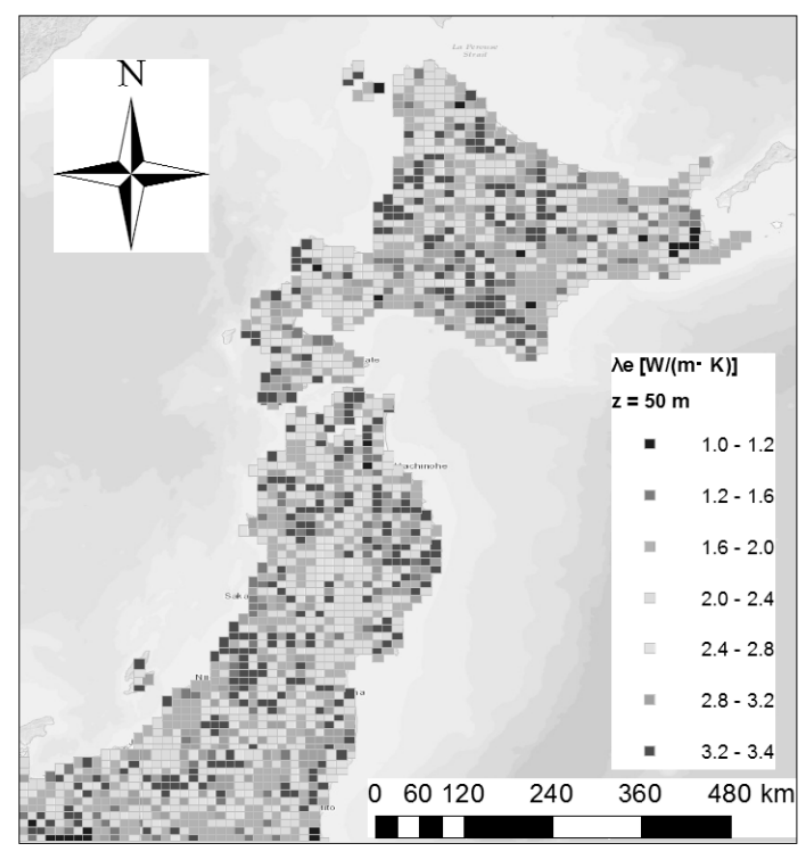

図-3 深度 $50 \mathrm{~m}$ までの平均有効熱伝導率

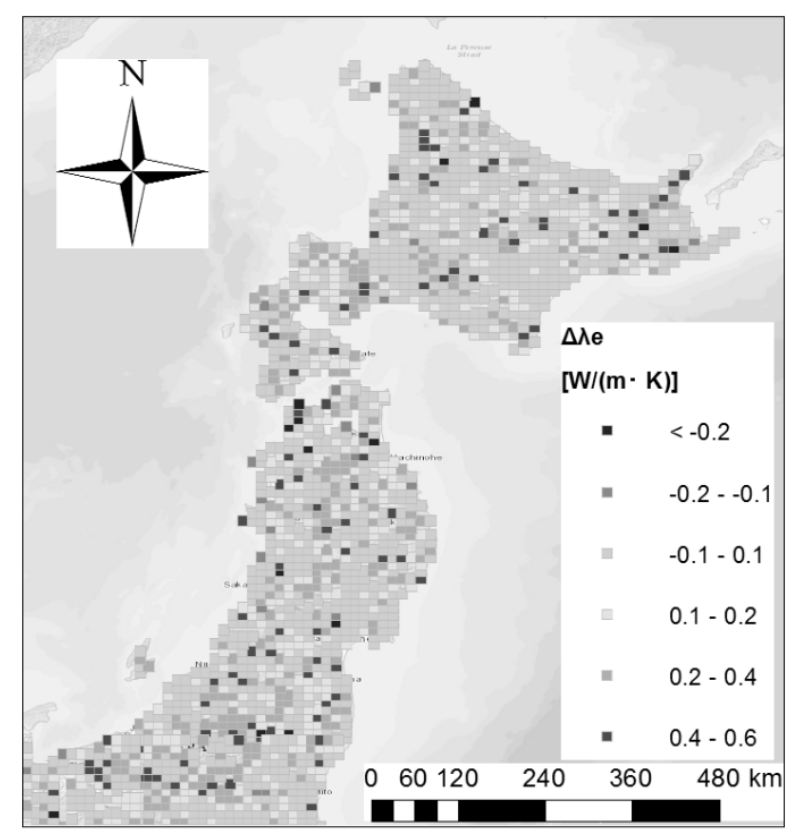

図-4 深度 $50 \sim 150 \mathrm{~m}$ 間の平均有効熱伝導率の増加量 
層 $(k=6$-7)が分布すると推定された.

本データベースでは，対象深度までの平均物性值を， 地表からその深度まで各グリッドで存在しうる全ての地 質区分の分布確率と固有物性值を掛け合わせて推定寸る。 有効熱伝導率の固有值 $\lambda_{k}(k=1 \sim 8)$ は, 収集した熱忘答試 験（76 箇所）を再現するよう最小二乗法で決定してい る 29. 推定誤差は, 地下水流れの影響が推測される試験 結果を除き, 約 $0.2 \mathrm{~W} /(\mathrm{m} \cdot \mathrm{K})$ であり, この值は有効熱伝 導率をパラメータとする感度解析によれば, GSHPs 導入 に必要な地中熱交換器長さに換算して約 $10 \mathrm{~m}$ の長さの 違いに相当する. なお本研究では, 有効熱伝導率への地 下水流れの影響は考慮していない，飽和・不飽和の判定 は，地下水面グリッドデータ ${ }^{35}$ を用い，不飽和帯の固有 有効熱伝導率は, 飽和帯の值の 0.7 倍を仮定した.

図-3は, $10 \mathrm{~km}$ グリッドでの深度 $50 \mathrm{~m}$ までの平均有効 熱伝導率 $\lambda_{\mathrm{e}}$ の分布である. 全体には $\lambda_{\mathrm{e}}=1.5 \sim 2.0 \mathrm{~W} /(\mathrm{m} \cdot \mathrm{K})$ 程度で, 基盤が浅い山地や丘陵地では $\lambda_{\mathrm{e}}=3.0 \mathrm{~W} /(\mathrm{m} \cdot \mathrm{K})$ 程 度の高い值となり，臨海部や河川沿いの平地においては $\lambda_{\mathrm{e}}=1.0 \mathrm{~W} /(\mathrm{m} \cdot \mathrm{K})$ 程度の低い值となった。

図-4 は, 深度 $50 \sim 150 \mathrm{~m}$ 間の有効熱伝導率の増加量 山 $\boldsymbol{e}_{\mathrm{e}}$ である，深度に向かって「土」から「岩」になるた め， $\Delta_{\mathrm{e}}$ は概初正の值となり，丘陵地や台地では「基盤 $(k=8) 」$ 出現割合が多くなるため值が大きくなる，一 方, $\Delta_{\mathrm{e}}=-0.1 \sim 0.1 \mathrm{~W} /(\mathrm{m} \cdot \mathrm{K})$ と変化が小さい地域も多い. これらの地域は, 深度 $150 \mathrm{~m}$ 付近まで未固結な「土」が 厚い堆積平野・盆地か，浅くに「基盤」が現れる山地か， $10 \mathrm{~km}$ グリッド内に井戸データがなく, 地質を「土」か 「岩」の2 種類のみで仮定したかのいずれかに該当する。 その他計算に用いる物性として, 体積熱容量は文献3 を参考に一定 $\left(3 \mathrm{MJ} /\left(\mathrm{m}^{3} \cdot \mathrm{K}\right)\right)$ と仮定した。 温度不易層の 深度と温度は，既往文献37がとりまとめた一連の成果 ${ }^{38)}$ 39)に基づき設定し，地温勾配は $3{ }^{\circ} \mathrm{C} / 100 \mathrm{~m}$ 一律仮定した。

\section{（2）地中熱ヒートポンプシステムシミュレーション}

本研究では，全国地盤物性データベースの入分布を用 い, GSHPsシミュレーションを行った. 計算には, わが 国で普及するGSHPs設計性能予測ツール「Ground Club」 40)を用いた. Ground Clubは, 地中熱交換器周辺の地盤温 度変化を理論解の重社合わせで計算することで, FEFLOWなどの有限要素法に比べ高速計算が可能で，か つヒートポンプのCOP条件など任意の条件変更に対応で きるため, 効率的な広域マッピングに特に有効である.

GSHPs導入を想定する建物は，平成25年省エネルギー 基準の解説書 ${ }^{41}$ （以下，解説書）と同じ標準戸建て住宅 を想定した. ただし熱負荷は暖房負荷のみを想定し，解 説書と同じ熱貫流負荷の時刻別定常計算を行った.

$Q_{\mathrm{h}}=U_{A} \times\left(T_{\mathrm{i}}-T_{\mathrm{o}}\right) \times A_{\mathrm{e}} \times \alpha, T_{\mathrm{i}}<T_{\mathrm{o}}$

ここで，Qhは暖房熱負荷 [W]，UAは外皮平均熱貫流率
$\left[\mathrm{W} /\left(\mathrm{m}^{2} \cdot \mathrm{K}\right)\right]$ で解説書に従い全国7地域区分の設定值 $\left(U_{A}=\right.$ 0.46 0.87 W/( $\left.\left.\mathrm{m}^{2} \cdot \mathrm{K}\right)\right)$ を用いた. $A_{\mathrm{e}}$ は外皮面積 $\left[\mathrm{m}^{2}\right]$ で想定 住宅の場合, $312 \mathrm{~m}^{2}$ (延床面積 $120 \mathrm{~m}^{2}$ ) である. $\alpha$ は負荷 補正率であり, 想定住宅の居住空間のみの暖房負荷を想 定した $(\alpha=0.68)$. $T_{0}$ は時刻別外気温 $\left[{ }^{\circ} \mathrm{C}\right] て ゙ ，$ 推定箇所近 傍の拡張アメダスデータ42)を用いた。拡張アメダスデー 夕は，統計期間が1980～2000年と最新の気象庁の平年值 の統計期間（1981～2010年）とほぼ同一であり，建築設 計に必要な様々な気象データが整備されることから, 現 在, 実務・研究双方に広く用いられている，Til暖房室 内設定温度 $\left[{ }^{\circ} \mathrm{C}\right]$ で, 解説書と同じ $<22^{\circ} \mathrm{C}$ 一定とした.

地中熱交換器は，鉛直埋設の間接型（クローズド）方 式とし, ボアホール掘削径 $120 \mathrm{~mm}, \mathrm{U}$ チューブを呼び径 $25 \mathrm{~A}$ シングル，ボアホールの充填材を珪砂 $\left(\lambda_{e}=1.5 \mathrm{~W} / \mathrm{m}\right.$ ・ K)）とし，熱媒体はエチレングリコール系不凍液を想定 した. 地中熱交換器長さLいは, $50 \mathrm{~m}$ から $225 \mathrm{~m}$ まで $25 \mathrm{~m}$ 間 隔，計8ケースにてシミュレーションを行った.

本研究では, 寒冷地では採熱に伴い地盤温度が $0{ }^{\circ} \mathrm{C}$ 下回る場合があるため, 潜熱を考慮した温度計算を行っ た. 潜熱考慮領域（凍結最大範囲）は地中熱交換器中心 から半径 $0.3 \mathrm{~m}$ の円筒領域を仮定し, 地盤温度を等温条 件 $\left(0{ }^{\circ} \mathrm{C}\right)$ とした温度回復法43)により計算した. その際, 時 刻別負荷の累積に応じて凍結領域をドーナツ状に増加さ せ, 凍結領域の間隙水が水 $\left(\lambda_{\mathrm{e}}=2.2 \mathrm{~W} /(\mathrm{m} \cdot \mathrm{K})\right)$ に凝固する際 の有効熱伝導率を定常直列モデルで計算した.

ヒートポンプのCOPは, 従来の計算では定格COP一定 を仮定することが多いが，COP特性が計算結果に大きく 影響する.ここでは住宅向け市販製品（定格出力 $Q_{0}=$ $10 \mathrm{~kW}$ ）の成績試験結果に基づき，暖房温度 $T_{2}$ out，1次側 計算入口温度 $T_{\mathrm{lin}}$, 部分負荷 (採放熱量と定格出力との比 $\left.Q / Q_{0}\right)$ それぞれの補正係数 $\varepsilon$ 二次式で近似し，基本 $\mathrm{COP}_{0}(=3.7)$ に掛け合わせて, 時刻毎のCOPを推定した.

$$
\begin{aligned}
& \mathrm{COP}=\mathrm{COP}_{0} \times \varepsilon_{1} \times \varepsilon_{2} \times \varepsilon_{3} \\
& \varepsilon_{j}=a_{j} x^{2}+b_{j} x+c_{j}
\end{aligned}
$$

ここで，xは補正係数㳊 0 要素で, $T_{2 \text { out }}(j=1), T_{\operatorname{lin}}(j=2)$, $Q / Q_{0}(j=3)$ のずれかである. 表-1に補正係数の一覧を示 す. 本研究で想定する市販製品のCOPの上限は4.5とした. また暖房機は，2型ファンコイルユニット6台とし，ヒー トポンプから暖房機への送水温度は $40{ }^{\circ} \mathrm{C}$ 一定とした.

計算手順として，まず1次側温度を(2)式による時刻別 暖房熱負荷に対LGround Clubを用いて計算する. 次いで, 計算温度と部分負荷率から(3.1), (3.2)式によりヒートポン

表-1 ヒートポンプのCOP特性式における補正係数

\begin{tabular}{ccrr}
\hline & $T_{1 \text { in }}(j=1)$ & $T_{2 \text { out }}(j=2)$ & \multicolumn{2}{c}{$Q / Q_{0}(j=3)$} \\
\hline$a$ & $7.00 \times 10^{-5}$ & $2.47 \times 10^{-2}$ & 1.80 \\
$b$ & $1.10 \times 10^{-3}$ & $1.94 \times 10^{-2}$ & 1.01 \\
$c$ & $3.30 \times 10^{-3}$ & 1.01 & 1.18 \\
\hline
\end{tabular}


プの時刻毎のCOPを求め, ヒートポンプの消費電力を計 算する. 一連の計算を初期温度から開始し，毎年同じ時 刻別負荷条件にて3年繰り返し，3年目の年間消費電力の 総和を計算した。 これと暖房熱総負荷の比として, GSHPN性能の目安となる期間平均COP $(\overline{\mathrm{COP}})$ を求めた.

\section{(3) 目標 $\overline{\mathrm{COP}}$ に対する地中熱交換器長さの決定}

GSHPs設計では，深度当たりの単位採放熱量(W/m)を 一定と仮定し, 暖冷房熱負荷に対応できる地中熱交換器 長さL告決定することが多い，ただし単位採放熱量は， その地点の $\mathrm{e}$ を反映し值が変わるほか, 同じ地点でも想 定寸るLが違えば值は変わりうる，そこで本研究では， GSHPsの目標 $\overline{\mathrm{COP}}(\operatorname{target} \overline{\mathrm{COP}}: \mathrm{t} \overline{\mathrm{COP}})$ を指標とし， t $\overline{\mathrm{COP}}$ 得るために必要な $L_{b}$ を地中熱交換器の必要長さとする.

図-5に，Lbを 50〜150 mにて10 m毎に変えた場合に，3 つの異なる $\lambda_{\mathrm{e}}(1.0,2.0,3.0 \mathrm{~W} /(\mathrm{m} \cdot \mathrm{K}))$ に対する $\overline{\mathrm{COP}}$ の計算 例を示寸，検討箇所は札幌市（緯度 $43.06^{\circ}$, 経度 $141.35^{\circ}$ ) である．なお地中熱交換器出口での熱媒体の最低温度の 下限を $-15^{\circ} \mathrm{C}$ と, 図-5では計算温度が下回る場合の結 果は除外している（ここでは， $\lambda_{\mathrm{e}}=1.0 \mathrm{~W} /(\mathrm{m} \cdot \mathrm{K})$ に対する $L_{b}=50 \mathrm{~m}, 75 \mathrm{~m}, \lambda_{\mathrm{e}}=2.0 \mathrm{~W} /(\mathrm{m} \cdot \mathrm{K})$ に対寸る $L_{b}=50 \mathrm{~m}$ の結果) . 図-5から，Lbに対し $\overline{C O P} は$ 連続的に増加し，その増加量 は はかが短い場合に大きく，Lが長い場合に小さいことが 分かる. 寸なわち, ג怔小さい地盤ではLbを長くするこ

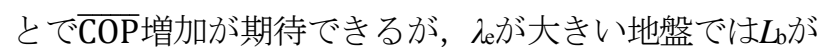

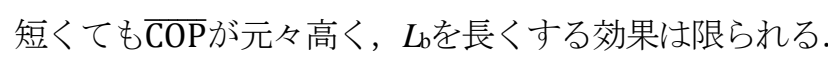
実際の地盤では $L_{b} の$ 変化に対し入 不易層温度や暖房熱負荷も箇所により異なる.このため, 本研究では, グリッド毎でLbの長さを変えたGSHPsシミ ユレーションを行い, $L_{b}$ と $\overline{\mathrm{COP}}$ の関係を逐次求めた. 次 に各グリッドの $L_{b}$ と $\overline{\mathrm{COP}}$ の関係を二次曲線で近似し，

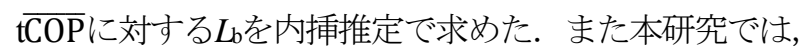
目標とするt $\overline{\mathrm{COP}}$ は，競合するASHPの寒冷地での実測

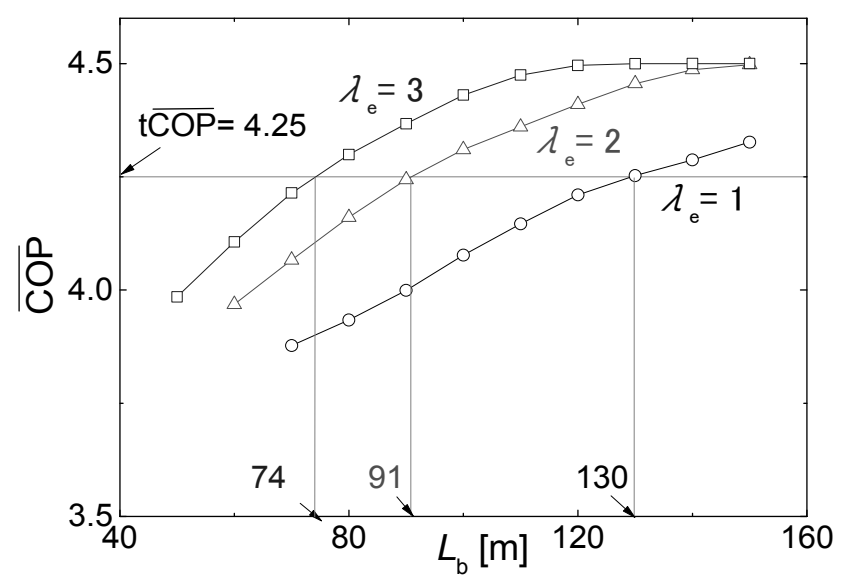

図-5 異なる平均有効熱伝導率の地盤における地中熱交換

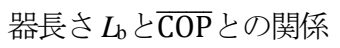

COPが 2.6程度 ${ }^{44)}$ であることと, 想定するGSHPのCOP上 限が4.5であることを考慮し， $\overline{\mathrm{COP}}=4.25$ と設定した．図5の例では， $\lambda_{\mathrm{e}}=1.0,2.0,3.0 \mathrm{~W} /(\mathrm{m} \cdot \mathrm{K})$ の場合に $\overline{\mathrm{COP}}=4.25$ を 得る必要長さはそれぞれ $L_{b}=74 \mathrm{~m}, 91 \mathrm{~m}, 130 \mathrm{~m}$ となる. こ の必要長さLbを検討対象とする北日本全体にて $10 \mathrm{~km} ク ゙$ リッドで計算し, マッピングした.

\section{(4) $\mathrm{CO}_{2}$ 排出量削減率の計算}

GSHPs 稼働に伴う $\mathrm{CO}_{2}$ 排出量は暖房熱総負荷を $\overline{\mathrm{COP}}$ で 除して消費電力とし，これに排出係数を乗じて計算する.

$W_{\mathrm{CO} 2}=\Sigma Q_{\mathrm{h}} / \overline{\mathrm{COP}} \times w_{\mathrm{E}}$

ここで，W $W_{\mathrm{CO} 2}$ は GSHPs 稼働時の $\mathrm{CO}_{2}$ 排出量 $\left[\mathrm{t}-\mathrm{CO}_{2} /\right.$ season $]$, $\Sigma Q_{\mathrm{h}}$ は暖房熱総負荷 $[\mathrm{kWh}]$ である。 $w_{\mathrm{E}}$ は電力使用時の排 出係数 $\left[\mathrm{t}-\mathrm{CO}_{2} / \mathrm{kWh}\right]$ で, 北海道電力, 東北電力, 東京電力, 北陸電力の管内で順に $6.69,5.56,5.00,6.27 \times 10^{4} \mathrm{t}-\mathrm{CO}_{2} / \mathrm{kWh}$ とした ${ }^{45}$. なお本研究では GSHPs 稼働時の排出量のみ 計算し, 設置や償却に伴う排出量は計算に含めなかった. 比較する既存暖房システムの熱源は，空気(ASHP)， 灯油, ガスのいずれかを仮定し, 統計資料 40から北日本 での普及率 $\beta_{l}(I=1 \sim 3)$ をそれぞれ $16,81,3 \%$ とした. 各熱 源の暖房機器を稼働した場合の $\mathrm{CO}_{2}$ 排出量に $\beta_{1}$ を掛け合 わせた和を既存システムの $\mathrm{CO}_{2}$ 排出量 $W_{\mathrm{CO} 2}$ 'とした.

$W_{\mathrm{CO} 2}=\Sigma Q_{\mathrm{h}}\left(1 / \overline{\mathrm{COP}}_{\mathrm{ASHP}} \times w_{\mathrm{E}} \times \beta_{1}+w_{\text {oil }} \eta_{\mathrm{Oil}} \times \beta_{2}+w_{\mathrm{Gad}} \eta_{\mathrm{Gas}} \times \beta_{3}\right)(5)$ ここで， $W_{\mathrm{CO} 2}$ 'は既存システムによる $\mathrm{CO}_{2}$ 排出量 [t$\mathrm{CO}_{2} /$ season]であり， $w_{\text {oill }}, w_{\text {Gas }}$ は灯油，ガス暖房それぞれの 排出係数 $\left[\mathrm{t}-\mathrm{CO}_{2} / \mathrm{kWh}\right]$ であり，ここでは理論值を用いた ${ }^{47)}$. $\eta_{\text {Oil, }} \eta_{\text {Gas }}$ は灯油, ガス暖房の燃焼効率であり, いずれも 0.85 とした. (4), (5)式より $W_{\mathrm{CO} 2}$ と $W_{\mathrm{CO} 2}$ 'を計算し, GSHPs 導入による $\mathrm{CO}_{2}$ 排出量削減率 $\Delta \mathrm{R}_{\mathrm{CO} 2}[\%]$ を求めた.

$\Delta \mathrm{R}_{\mathrm{CO} 2}=\left(1-W_{\mathrm{CO} 2} / W_{\mathrm{CO} 2}{ }^{\prime}\right) \times 100$

本研究では, $L_{b}=100 \mathrm{~m}$ の GSHPs を戸建て住宅へ導入す る場合の $\Delta \mathrm{R}_{\mathrm{CO} 2}$ をグリッド計算し，マッピングした.

\section{3. 結果と考察}

\section{（1）暖房熱負荷と期間平均COP}

図-6に，年間の暖房熱総負荷 $\Sigma Q_{\mathrm{h}}$ の計算結果を示す. $\Sigma Q_{\mathrm{h}}$ は検討地域では12000 28000 kWh程度であり，全般 には北に位置するほど值が大きいが，南の地域でも $U_{A}$ が小さくなるため, 高地等で局所的に值が大きくなる.

図-7に, わが国の標準的な地中熱交換器長さである $L_{b}=100 \mathrm{~m} の$ 場合で計算したGSHPs $の \overline{\mathrm{COP}}$ を示す. 東北以 南では, $\Sigma Q_{\mathrm{h}}$ が小さく不易層温度も高いため, 採熱によ る地盤温度の低下（地中熱交換器の熱交換温度差）は相 対的に小さい. このため, GSHPsのCOPは高地などの一 部を除き, 上限COPに近い $\overline{\mathrm{COP}}=4.4$ 前後と計算された.

一方，北海道では， $\Sigma Q_{\mathrm{h}}$ が大きく不易層温度も低いため, $\overline{\mathrm{COP}}$ は東北以南に比べ低くなる，ただし，北海道でも全 


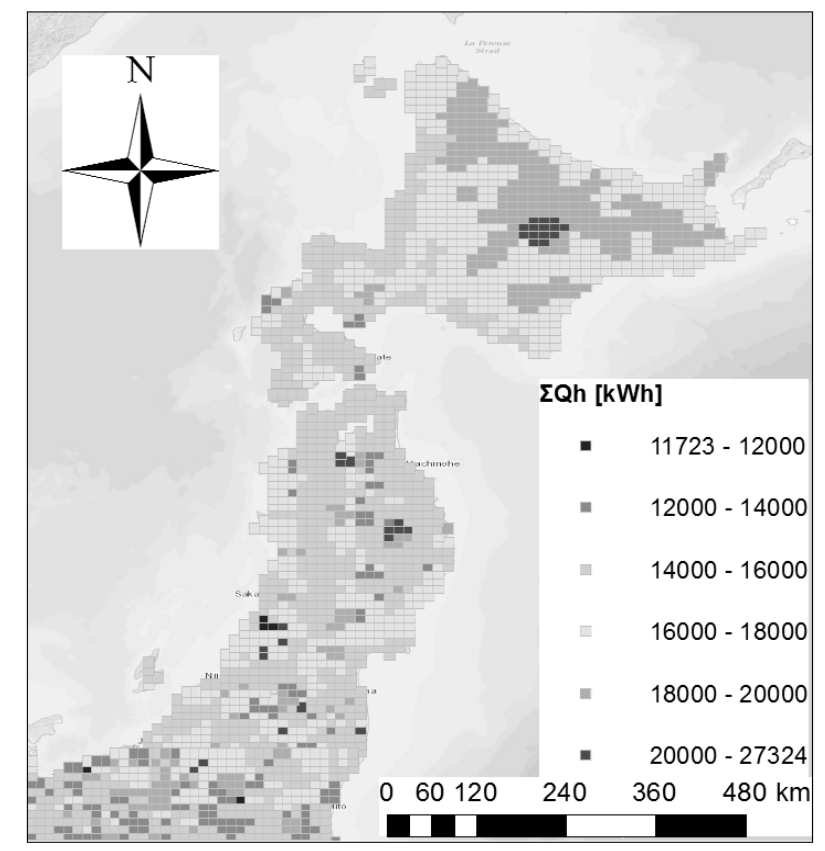

図-6 年間（シーズン）での暖房熱総負荷

体に $\overline{\mathrm{COP}}=4$ 前後は見込める結果となった.

図-8は，10 kmグリッドの各地点にて $L_{b}=50,75,100 \mathrm{~m}$ と

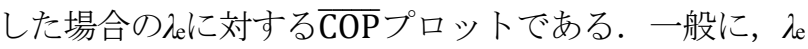
が大きいほどCOPが高くなる。この正の相関は図-8では, $L_{b}=50 \mathrm{~m}$ かつ $\lambda_{e}<2.0 \mathrm{~W} /(\mathrm{m} \cdot \mathrm{K})$ の場合に顕著に認められる.

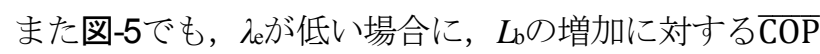
の増加が大きくなる傾向が示された，以上からGSHP導 入コスト低減のために $L_{b}$ を短くする場合には地盤条件( $\left(\lambda_{e}\right)$ が $\overline{\mathrm{COP}}$ により影響を与える可能性に留意が必要である. 一方，図-7から標準長さ $L_{b}=100 \mathrm{~m}$ の場合は地点によらず COPは4.0前後かそれ以上は見込まれることから，想定 した戸建て住宅とヒートポンプ性能でのGSHP導入の場 合には, 先ず標準長さで設計する選択肢も考えられる.

\section{(2) 目標期間平均COPを得るための地中熱交換器長さ}

図-9に, $t \overline{\mathrm{COP}}=4.25$ の場合に必要なLbのマップを示す. また図-10には，北海道，東北6県，北関東・北陸に分け た場合のL洼のボックスプロットを示す，必要長さ（中央 值）は，暖房負荷の大きい北海道で長 $\left\langle L_{b}=128 \mathrm{~m}\right.$, 東 北では $L_{b}=82 \mathrm{~m}$, 北関東・北陸では $L_{b}=76 \mathrm{~m}$ と試算された。 暖房負荷が大きい北海道で必要な $L_{b} か ゙$ 長く, 東北と北関 東・北陸での差は小さかった. 標準偏差は概ね $15 \mathrm{~m}$ 前後 であるが，5～95\%範囲は北海道で中央值に対し $\pm 50 \mathrm{~m}$, 東北や北関東・北陸では $\pm 30 \mathrm{~m}$ 程度と比較的大きい。 ま たグリッド単位で見る場合, $\lambda_{\mathrm{e}} や \Sigma \mathrm{Q}_{\mathrm{n}}$ の違いによって, 隣接グリッドでも $\mathrm{b}_{\mathrm{b}}$ 少20〜 $40 \mathrm{~m}$ 程度異なって計算される.

標準長さ $L_{b}=100 \mathrm{~m}$ と比較する場合, 東北以南では $\overline{\mathrm{COP}}=4.25$ を得る必要長さ（中央值）は約 $20 \mathrm{~m}$ 短くなり， 設置コストの縮减が見込める. 一方, 北海道での必要長

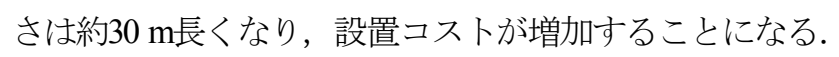

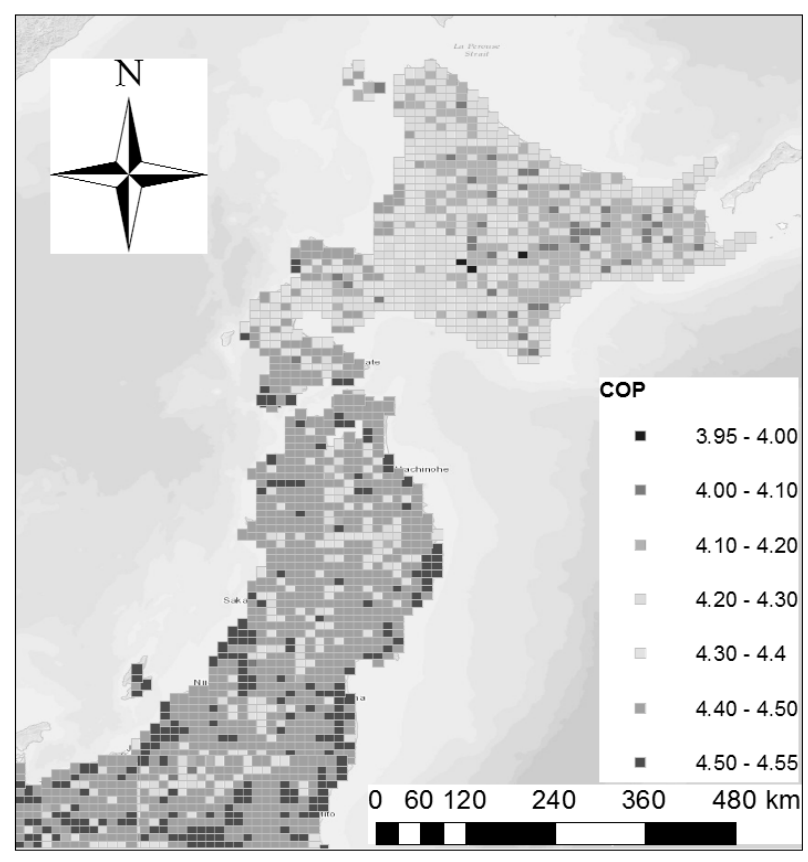

図-7 地中熱交換器長さ $L_{b}=100 \mathrm{~m}$ の場合の $\overline{\mathrm{CO}} \overline{\mathrm{P}}$

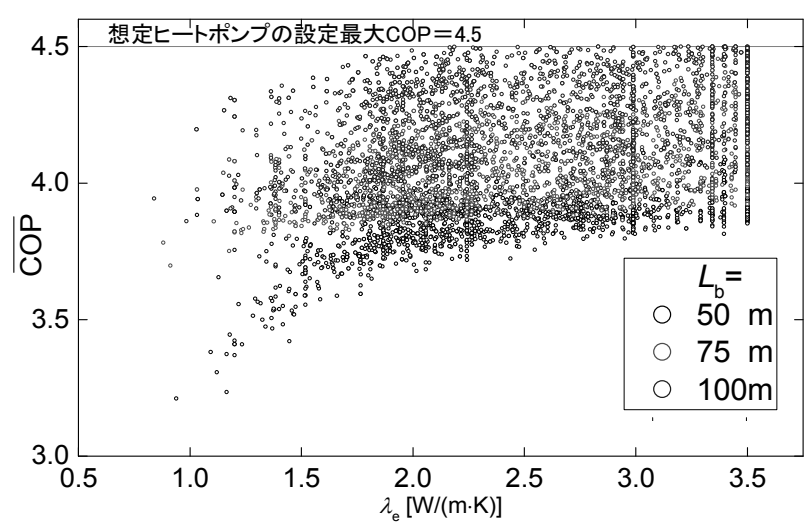

図-8 有効熱伝導率 $\lambda_{\mathrm{e}}$ と $\overline{\mathrm{COP}}$ の関係

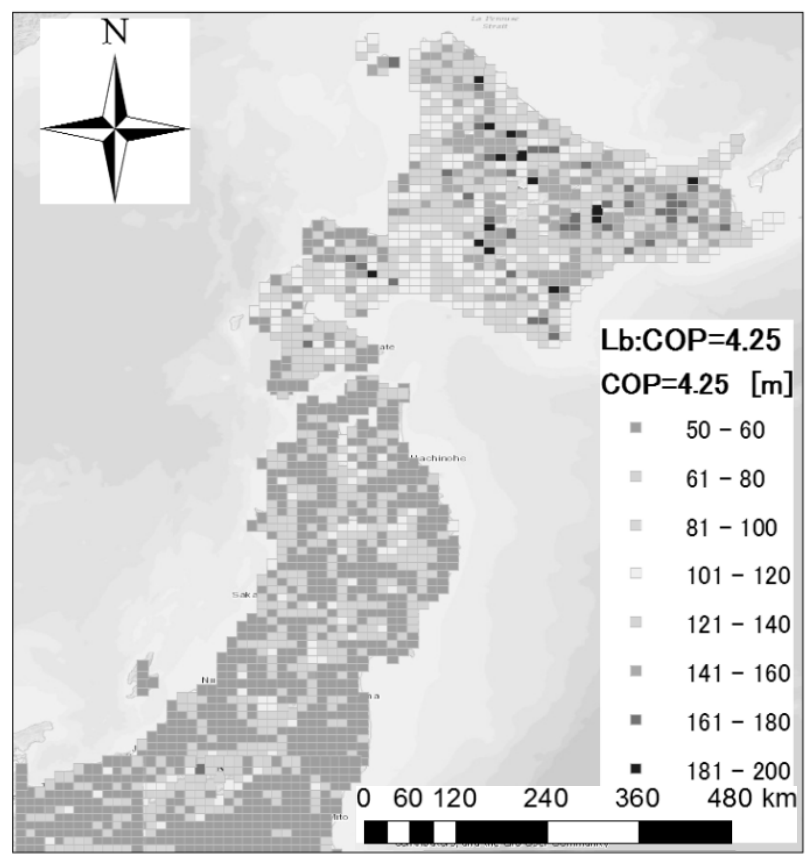

図-9 $\mathrm{t} \overline{\mathrm{COP}}=4.25$ を得るために必要な地中熱交換器長さ $L b$ 
このため，実際の設計でLbを検討する場合には， $\overline{\mathrm{COP}}$ 増 加によるコスト低減との比較が必要となる。 また，これ らの評価は地域毎の目安に過ぎず，図-9で隣接グリッド 間でLが異なることからも， $\lambda_{\mathrm{e}} や Q_{\mathrm{h}}$ など各地点の設計条 件に基づくシミュレーションを個別に行い，適切なLbを 検討していく必要がある. シミュレーションに用いる の入手には，熱空答試験を行う費用・時間的制約を考慮 すると，先ずは本データベースの活用が有効であり，デ 一タベースの入荗 $2 \mathrm{~W} /(\mathrm{m} \cdot \mathrm{K})$ を下回ると予想される場合,

図-8より入 の不確実性に $\overline{\mathrm{COP}}$ が影響を受ける可能性から, 熱応答試験により入を実測するという手順が考えられる.

\section{(3) $\mathrm{CO}_{2}$ 排出量削減率}

図- 11 に， $L_{b}=100 \mathrm{~m}$ の GSHPs を導入した戸建て住宅 の暖房使用時の $\Delta \mathrm{R}_{\mathrm{CO} 2}$ を示寸. 電力会社によって計算に 用いる電力使用時の排出係数 $w_{\mathrm{E}}$ が異なるため, 事業範 囲の境界で $\Delta \mathrm{R}_{\mathrm{CO} 2}$ の分布が不連続となるが，北日本全体 では未だ灯油暖房が占める割合が大きいため $\left(\beta_{2}=81 \%\right)$, 高効率な GSHPs を導入することで $\Delta \mathrm{R}_{\mathrm{CO} 2}=45 \sim 60 \%$ 程度 の高い環境負荷低減効果が期待できることが分かる.

図- 12 に，北海道，東北 6 県，その他北関東 - 北陸 での $\Delta \mathrm{R}_{\mathrm{CO} 2}$ のボックスプロットを示す，本計算では，既 存システムの暖房熱源の割合 $\beta_{l}$ を一律としたため, $\Delta$ R $\mathrm{CO} 2$ は総負荷量, GSHPs $の \overline{\mathrm{COP}}$ おび電気使用時の排出 係数に依存する. $\overline{\mathrm{COP}}$ が相対的に低くかつ $w_{\mathrm{E}}$ が大きい 北海道では $\Delta \mathrm{R}_{\mathrm{CO} 2}=$ 中央值 $45 \%$ 土標準偏差 $1 \%$ 程度に留

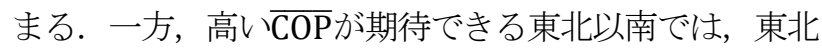
で $\Delta \mathrm{R}_{\mathrm{CO} 2}=54 \% \pm<1 \%$, 関東・北陸で $\Delta \mathrm{R}_{\mathrm{CO} 2}=58 \%$-4 $+1 \%$ 高い值となる. ただし北陸電力管内は $w_{\mathrm{E}}$ が大き いため, $\Delta \mathrm{R}_{\mathrm{CO} 2}$ が小さく関東・北陸のボックスを下方向 に拡大させている，ただし，いずれの地域も $\Delta \mathrm{R}_{\mathrm{CO} 2}$ の標 準偏差は小さく, 隣接グリッドの変化は $1 \%$ 程度であり, t $\overline{\mathrm{COP}}$ 得るための $L_{b}$ (図-9）の場合と異なり， $\Delta \mathrm{R}_{\mathrm{CO} 2}$ の 比較は地域（電力会社管内）単位で可能である.

本研究により, 灯油暖房が主流な北日本では GSHPs の導入に伴い高い環境負荷低減効果が広範囲に得られる ことが改めて示された. 現在, GSHPs 導入は北海道で先 行するが 4$)$, 東北以南では比較的短い $L_{\mathrm{b}}$ で高い $\overline{\mathrm{COP}}$ が得 られ， $\Delta \mathrm{R}_{\mathrm{CO} 2}$ も比較的大きい值が見込めることが分かり， 今後, GSHPs の積極的な導入が期待される.

このように広域での地中熱ポテンシャルマップは，地 域単位での GSHPs 導入可能性を視覚的に明らかにする ことで，地域毎のポテンシャルを考慮した GSHPs の普 及促進を働きかけることが可能となる. また地球温暖化 対策としての環境負荷低減効果を地域・国レベルで評価 寸る上で, 広域マッピングは特に有効であり, 今後, 北 日本だけでなく日本全体を対象に整備を進めていきたい.

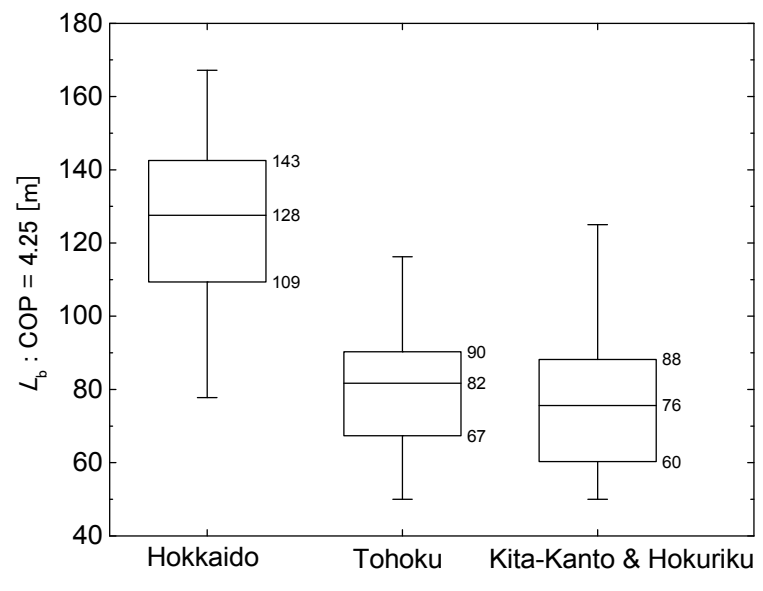

図-10 必要地中熱交換器長さ $L_{b}$ の地域別ボックスプロット

(ボックス : 中央值士標準偏差，バー：5-95\%範囲)

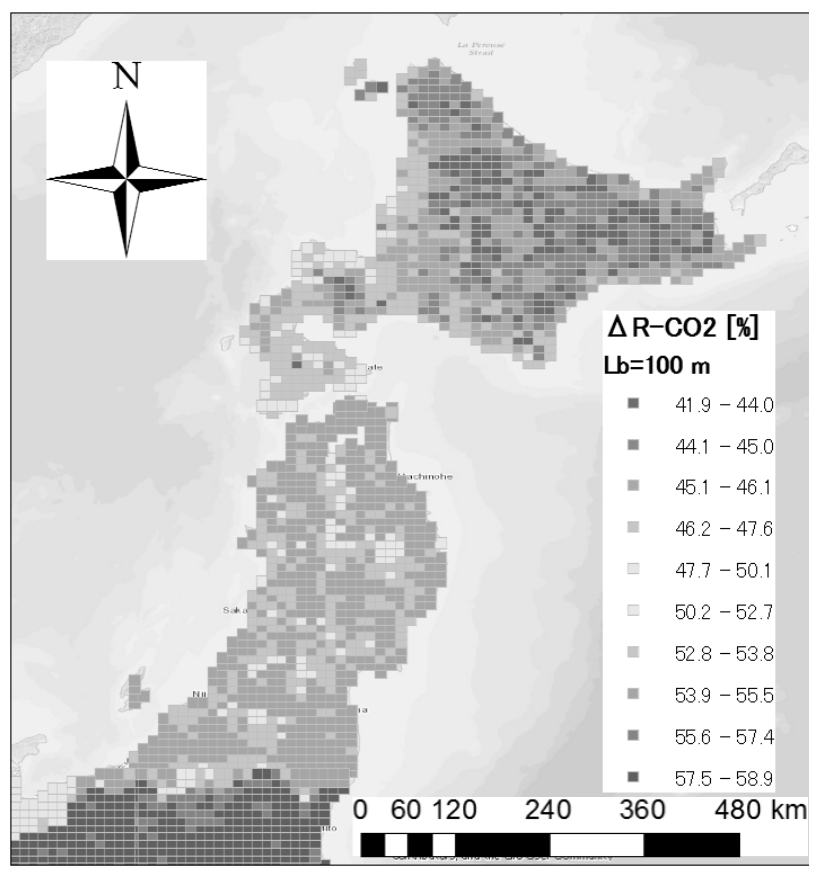

図-11 暖房利用 GSHPs 導入による戸建住宅の $\mathrm{CO}_{2}$ 排出量削減 率（地中熱交換器長さ $L_{b}=100 \mathrm{~m}$ の場合）

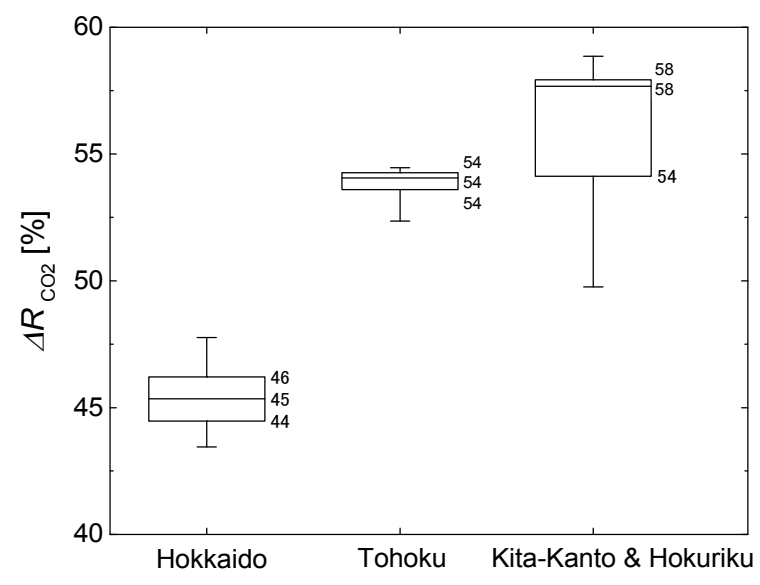

図-12 $\mathrm{CO}_{2}$ 排出量削減率の地域別ボックスプロット （地中熱交換器長さ $L b=100 \mathrm{~m}$ の場合） 


\section{4. まとめ}

本研究では，地中熱利用を想定する深度 $100 \mathrm{~m}$ 付近ま でをカバーする全国地盤物性データベースの有効熱伝導 率の推定分布を用い，想定した標準戸建て住宅に地中熱 利用ヒートポンプシステムGSHPsを北日本全体に導入す る場合の期間平均成績係数 $\overline{\mathrm{COP}}$ ，必要な地中熱交換器長 さ $\mathrm{b}_{\mathrm{b}}$ 及び $\mathrm{CO}_{2}$ 排出量削減率 $\Delta \mathrm{RCO}_{2}$ を計算し, 地中熱ポテ ンシャルマップとして示した. 以下に結果をまとめる.

・データベースによる深度方向の有効熱伝導率入 は, 北日本全体では $\lambda_{\mathrm{e}}=1.5 \sim 2 \mathrm{~W} /(\mathrm{m} \cdot \mathrm{K})$ 程度で分布し, 山地や 丘陵地では祀 $=3 \mathrm{~W} /(\mathrm{m} \cdot \mathrm{K})$ 程度まで高く, 臨海部や河川沿 いの平地では $\lambda_{\mathrm{e}}=1 \mathrm{~W} /(\mathrm{m} \cdot \mathrm{K})$ 程度まで低くなると推定され た. また深度方向に緩やかに増加する傾向が示された.

・必要な地中熱交換器長さ $L_{b} の$ 計算法として， $L_{b}$ を変 えた場合の入の変化を考慮した地中熱シミュレーション を行い, 各地点毎に $L_{b}$ と $\overline{\mathrm{COP}}$ との関係を求め, 目標 $\overline{\mathrm{COP}}$ を得るためのLを挿推定する手法を提案した。

・わが国における標準長さ $L_{b}=100 \mathrm{~m}$ によるGSHPsを導 入する場合, 北日本全体で $\overline{\mathrm{COP}}$ は4.0程度かそれ以上と なり，標準長さを設計に用いる妥当性を確認できた.よ り合理的なGSHPsとして目標 $\overline{\mathrm{COP}}=4.25$ を設定する場合, 東北以南では必要なLbは80 m程度と標準長さに比べより 短く済み, 設置コストが縮減できる可能性が示された. 一方, 北海道では $L_{b} は 130 \mathrm{~m}$ 程度とより長く必要と計算 された. この場合には，設置コストと的増大による稼 働コストを比較し，適切な $L_{b}$ を決定していく必要がある。

・GSHPs導入による戸建て住宅の暖房時の $\Delta$ Rco2は 45 〜 $60 \%$ 程度となり，未だ灯油暖房の占める割合が大きい 北日本で高い導入効果が見込まれた．特に電力使用時の 排出係数が小さい東北以南では $\Delta \mathrm{R} \mathrm{co} 2$ は比較的大きくな ると試算され， $\overline{\mathrm{COP}}$ も北海道に比べ高い值が期待できる ことから, 今後, GSHPsの一層の普及が期待される.

なお本研究では地下水流れによる地中熱利用の効率向 上効果が考慮されていない. このため, 地下水が豊富で, 動水勾配の大きい山間部や扇状地などでは，GSHPsの導 入効果が過小評価されている可能性が高い. このため, データベースに地下水流れの情報も加えるとともに，複 層地盤・地下水流れを考慮した計算手法 ${ }^{25}$ を導入するこ とで，移流効果も含めた地中熱ポテンシャルの評価を改 めて行う必要がある。また今後，北日本のみならず，冷 房需要も含めた日本全体一検討対象を拡大し，住宅・非 住宅など様々な建物から構成される実際の都市条件を考 慮した計算を行い，分析精度を高めていきたい.

謝辞 : 本研究は，NEDO再生可能エネルギ一熱利用技術 開発事業として進められた。全国地盤物性データベース 構築に際して，産業技術総合研究所の丸井敦尚博士及び
地中熱利用促進協会の笹田政克博士から貴重なご意見を 頂くとともに，データ整備では（株）日伸テクノ及び本 研究室の院生らから協力を得た。また本計算に必要な Ground Clubの改良に際し, ジーエムラボ（株）の協力を 得た.ここに記し謝辞とします.

\section{参考文献}

1) 長野克則：地下熱利用技術 2. 地下熱利用技術とは, 地下水学会誌, Vol. 53, No. 1, pp. 83-90, 2011.

2) Nagano, K. : The progress of GSHP in Japan. IEA Heat Pump Centre News Letter, Vol. 33, No. 3, pp. 21-25, 2015.

3) 環境省: 平成 28 年度地中熱利用状況調査の結果, 報 道発表資料, http://www.env.go.jp/press/103827.html， (2017.3.31 閲覧)

4) 藤塚哲朗, 佐藤郁太郎, 坪谷剛：地中熱を利用した ヒートアイランド対策技術の地盤環境への影響評価, 地球環境シンポジウム講演論文集, Vol. 15, pp. 183188, 2007.

5) 笹田政克, 高杉真司, 舘野正之 : 都心での地中熱利 用一小規模オフィスビルへの地中熱ヒートポンプシ ステムの導入一, 応用地質, Vol. 51, No. 6, pp. 265272, 2010.

6) 岡田浩一, 山崎智雄, 鶴田祥一郎, 中野勝行, 金岩 貢，平野彰秀，岡村鉄兵：地中熱利用事業及び小水 力発電事業の評価, 地球環境シンポジウム講演論文 集, Vol. 21, pp. 43-48, 2013.

7) 石上孝, 渡部敦史, 石黒幸治, 辻弘一, 谷口聡子, 大島和夫 : 地中熱利用冷暖房・融雪システムの概要 と長期運転実績評価, 建築設備と配管工事, Vol.48, No.2, p.39-44, 2010.

8) 建築環境・省エネルギー機構：一次エネルギー消費 量及び基準達成率算定支援ツール, http://ees.ibec.or.jp/tool/index.php，(2016. 12.10閲覧).

9) 内田洋平, 吉岡真由美 : 3.3.5 地中熱ポテンシャル評 価, 日本地熱学会 : 地熱エネルギーハンドブック, pp. 461-479, 2014.

10）濱田靖弘, 田中慎哉, 長野克則, 田村裕, 滝川郁美, 中村靖, 丸谷薰, 高清水康博, 高田雅之: 国土数值 情報を用いた地下熱利用システムの導入可能性に関 寸る研究, 空気調和・衛生工学会論文集, Vol. 143, pp. 1-10, 2000.

11) 内田洋平, 與田佑季, 藤井光, 宮本重信, 吉岡真 弓：地中熱利用適地の選定方法その 1 地下水流動・ 熱輸送解析と GIS を用いた地中熱利用適地マップの 作成, 日本地熱学会誌, Vol. 32, No. 4, pp. 229-239, 2010

12) 吉岡真弓, 内田洋平, 與田佑季, 藤井光, 宮本重信 : 地中熱利用適地の選定方法その 2 地下水流動・熱輸 送解析を用いた熱交換量マップの作成, 日本地熱学 会誌, Vol. 32, No. 4, pp. 241-251, 2010.

13) 大谷具幸, 河地浩平, 小嶋智, 笹田政克 : 自然条件 と社会条件を考慮した地中熱利用の広域的な賦存量 と導入ポテンシャルの評価手法, Vol. 35, No. 1, pp. 17-31, 2013.

14) 富樫聡, 西山浩平, 山本晃, 壇智之, 高橋勉: 広域 を対象とする地中熱ポテンシャル評価手法の提案, 
日本地下水学会 2013 年春季講演会講演要旨集, pp. 104-109, 2013.

15) シュレスタ ガウラブ, 内田洋平, 吉岡真弓, 藤井光, 井 岡聖一郎：地中熱ヒートポンプシステムにおけるポ テンシャルマップの高度化 , 日本地熱学会誌, Vol. 37, No. 4, pp. 133-141, 2015

16）環境省：平成 24 年度再生可能エネルギーに関するゾ 一ニング基礎情報整備報告書，平成 24 年度再生可能 エネルギーに関するゾーニング基礎情報整備報告書, pp. 183-206, 2013.

17) 岐阜県・岐阜市・帝国建設コンサルタント：地中熱 利用可能性調查, 201p., 2011.

18）黑石市：黒石市地中熱利用ポテンシャル調査事業報 告書, $188 p$., 2011.

19) 青森県：青森県地中熱・温泉熱利用ポテンシャル調 査事業報告書, 219p., 2012.

20) 東京都：東京都地中熱ポテンシャルマップ, http://www.kankyo.metro.tokyo.jp/energy/renewable_ener gy/ne2/tichumap/index.html, 2015，(2017.3.10閲覧).

21) 生田目修士：NEDO におけるポテンシャルマップの 取組, 第 24 回地中熱利用シンポジウム講演資料, 地 中熱促進協会, 2017.

22）日本熱物性学会編：新編熱物性ハンドブック，776p., 養賢堂, 2008.

23) Farouki, O.-T. : Thermal properties of soils, CRREL Monograph 81-1, United States Army Corps of Engineers, Cold Regions Research and Engineering Laboratory, Hanover, N.H., 137 p., 1981.

24）葛隆生，長野克則，中村靖：複層地盤を考慮した地 中熱交換器のシミュレーションツールの開発とその 応用，日本冷凍空調学会論文集，Vol. 32，No. 3, pp. 335-344, 2015.

25）国土交通省, 土木研究所, 港湾空港技術研究所 : 国 土地盤情報検索サイト「KuniJiban」 http://www.kunijiban.pwri.go.jp/jp/. (2016.3.18 閲覧).

26) 新エネルギー・産業技術総合開発機構（NEDO）：再 生可能エネルギー熱利用技術開発, http://www.nedo.go.jp/activities/ZZJP_100067.html ， (2017.1.15 閲覧).

27) 阪田義隆, 葛隆生, 長野克則, 丸井敦尚 : 井戸デー タベースを用いた地盤情報推定システムの開発 : 地 質区分のクリギング推定と逐次パラメータ決定法, 地下水学会誌, No. 59 (2), 105-123, 2017.

28）阪田義隆, 橋本隼樹, 葛隆生, 長野克則 : 地盤・地 下水データベースに基づく地中熱利用ポテンシャル マップと設計性能予測ツールの開発その 3 地質区分 の予測分布確率を用いた熱・水理物性值の推定, 空 気調和・衛生工学会北海道支部第 51 回学術講演会論 文集， 2017 .

29) 丸井敦尚：地質調査所版全国井戸・水文データベー スの概要と新版「いどじびき」について，地質ニュ
一ス, 522, pp. 32-36, 1998.

30）国土交通省：全国地下水（深井戸）資料台帳, http://nlftp.mlit.go.jp/kokjo/inspect/landclassification/wate r/basis/underground/F9/exp.html，(2016.9.16 閲覧).

31）越谷賢，丸井敦尚，伊藤成輝，吉澤拓也：日本列島 における三次元水文地質モデルの構築と地下水賦存 量の試算, 地下水学会誌, Vol. 53, No. 4, pp. 357-377, 2011.

32) 日本第四紀学会：第四紀の定義，http://quaternary. jp/news/teigi09.html，(2017.5.31 閲覧).

33) Deutsch, C.V.: Geostatistical reservoir modeling, 376p., Oxford University Press, 2002.

34）国土交通省：国土数值情報（土地分類メッシュ）, http://nrb- www.mlit.go.jp/ksj/. (2015.10.4 閲覧).

35) 越谷賢, 丸井敦尚：日本全国の地盤調査ボーリング データを用いた地形・地質条件に基づく地下水面の 推定, 地下水学会誌, Vol. 53, No. 2, pp. 179-191, 2011.

36) 北海道大学地中熱利用システム工学講座 : 地中熱七 ートポンプシステム, pp. 92-99, オーム社, 2007.

37) 新居正 : 地域分析のための熱 - 水収支水文学, pp. 142-145, 古今書院, 2004.

38) 木内四朗兵衛 : 土壤気象の研究, 地学雑誌, No. 59, pp. 88-92, 1950.

39) 大和田道雄：日本における地中温度の分布について, 地理学評論, No. 42, pp.138-144, 1969.

40）地中熱利用促進協会：地中熱ヒートポンプシステム 施工管理マニュアル，pp.33-37，オーム社，2014.

41) 国土交通省国土技術政策総合研究所, 建築研究所： 省エネルギーに準拠した算定・判断の方法及び解説 II 住宅 , 1082p., 2013.

42) 日本建築学会：拡張アメダス気象データ 1981-2000, 223p., 日本建築学会, 2005.

43) 大中逸雄 : コンピュータ伝熱 - 凝固解析入門, pp.193-208，丸善， 1985 .

44) 野川貴史, 本郷一郎, 石川光浩, 清水克浩 : 寒冷地 住宅に適したルームエアコンの開発とフィールド計 測, 平成 22 年度空気調和・衛生工学会学術講演会論 文集，pp. 2019-2022，2010。

45) 三菱総合研究所: 平成 24 年度エネルギー消費状況調 查（民生部門エネルギー消費実態調查）報告書, pp. 38-61, 2013.

46) 環境省：電気事業者別排出係数（特定排出者の温室 効果ガス排出量算定用）一平成 26 年度実績一, 報道 発表資料， http://www.env.go.jp/press/101746.html， 2015, (2016. 12.10閲覧).

47) 日本 LP ガス協会 : 燃料の排熱量 - CO2 排出係数, http://www.j-lpgas.gr.jp/nenten/data/co2_ichiran.pdf , (2016.12. 10 閲覧) . 


\title{
REGIONAL EFFECIENCY ANALYSIS OF GROUND SOURCE HEAT PUMP SYSTEMS WITH GEO-PROPERTY DATABASE
}

\author{
Yoshitaka SAKATA $^{1}$, Takao KATSURA ${ }^{2}$ and Katsunori NAGANO ${ }^{6}$
}

${ }^{1}$ Faculty of Engineering, Hokkaido University

The purpose of this study is to evaluate an efficiency of ground source heat pump systems (GSHPs) in a standard residensial on a regional scale by the numerical simulation with the three-dimensional database of the effective thermal conductivity. The database was constructed through the indicator-kriging procedure based on the available borehole and water-well data to cover the depths beyond about $100 \mathrm{~m}$ for installation of borehole heat exchangers (BHEs). This study also proposed the methodology to determine required lengths of BHEs for a target value of seasonally averaged coefficients of performance $(\bar{t} \overline{\mathrm{COP}})$ in the GSHPs. The GSHPs simulation was demonstrated by using the Ground Club algorithm in a regular grid of $10 \mathrm{~km}$ over the northern area (the latitude $>36^{\circ}$ ) of Japan. First, this study showed that the $\overline{\mathrm{COP}}$ values were calculated at about 4.0 in the Hokkaido area and about 4.4 in the Tohoku and northern Kanto areas when the BHE was assumed to be a standard length of $100 \mathrm{~m}$. Next, the required median length of $\mathrm{BHE}$ for $\mathrm{t} \overline{\mathrm{COP}}=4.25$ was estimated at about $80 \mathrm{~m}$ in the Tohoku and the northern Kanto areas. The smaller BHE length means that the intial costs for GSHPs could be efficiently reduced. On the other hand, the required median length was about $130 \mathrm{~m}$ in the Hokkaido area because the heating loads were relatively high in the cold region. The reduction ratio of $\mathrm{CO}_{2}$ emissions was estimated at about 45-60\% when the ground source heat pump systems were utilized over the area instead of the conventional electric, oil and gas boiler systems. The reduction ratio was relatively large in the Tohoku and northern Kanto areas, indicating the potential increase of GSHPs in the future. 